\title{
Effect of reducing the period of follicle dominance in a timed artificial insemination protocol on reproduction of dairy cows
}

\author{
J. E. P. Santos, ${ }^{* 1,2}$ C. D. Narciso, ${ }^{*}$ F. Rivera, ${ }^{*}$ W. W. Thatcher, ${ }^{*}$ and R. C. Chebel ${ }^{2}$ \\ *Department of Animal Sciences, University of Florida, Gainesville 32611 \\ †Department of Veterinary Population Medicine, University of Minnesota, St. Paul 55108
}

\begin{abstract}
Objectives were to determine the effect of reducing the period of follicle dominance in a timed artificial insemination (AI) protocol on pregnancy per $\mathrm{AI}(\mathrm{P} /$ $\mathrm{AI})$ in Holstein cows. In experiment 1,165 cows received 2 injections of $\mathrm{PGF}_{2 \alpha}$ at 36 and $50 \mathrm{~d}$ in milk (DIM). At 61 DIM, cows were assigned randomly to Cosynch 72 h (CoS72: d 61 GnRH, d $68 \mathrm{PGF}_{2 \alpha}$, d 71 GnRH) or to a 5-d Cosynch $72 \mathrm{~h}$ with 1 (5dCoS1: d $61 \mathrm{GnRH}$, d $66 \mathrm{PGF}_{2 \alpha}$, d $\left.69 \mathrm{GnRH}\right)$ or 2 injections of $\mathrm{PGF}_{2 \alpha}$ (5dCoS2: d $61 \mathrm{GnRH}, \mathrm{d} 66$ and $67 \mathrm{PGF}_{2 \alpha}$, d $69 \mathrm{GnRH})$. Blood was sampled at the first GnRH, first $\mathrm{PGF}_{2 \alpha}$, and at the second $\mathrm{GnRH}$ of the protocols and assayed for progesterone. Ovulatory responses to GnRH were evaluated by ultrasonography. Cows were considered synchronized if they had concentrations of progesterone $\geq 1 \mathrm{ng} / \mathrm{mL}$ and $<1 \mathrm{ng} / \mathrm{mL}$ on the days of the $\mathrm{PGF}_{2 \alpha}$, and the second GnRH of the protocols, respectively, and if they ovulated within $48 \mathrm{~h}$ of the second GnRH injection. In experiment 2, 933 cows were assigned randomly to CoS72 or $5 \mathrm{dCoS} 2$. Blood was assayed for progesterone and ovaries were scanned as in experiment 1. Plasma on the days of the first $\mathrm{PGF}_{2 \alpha}$ and final GnRH of the timed AI protocols was assayed for estradiol in 75 cows. Pregnancy was diagnosed on d 38 and 66 after AI. In experiment 1, the proportions of cows with corpora lutea (CL) regression on the day of AI differed and were 79.0, 59.1, and 95.7\% for CoS72, $5 \mathrm{dCoS} 1$, and $5 \mathrm{dCoS} 2$, respectively. Cows that ovulated to the first GnRH of the Cosynch tended to have lesser CL regression than cows that did not ovulate (73.0 vs. $86.4 \%$ ). Protocol synchronization differed between treatments and they were greater for CoS72 (69.4\%) and $5 \mathrm{dCoS} 2(78.4 \%)$ than for $5 \mathrm{dCoS} 1$ (42.3\%). In experiment 2, CL regression was lesser (91.5 vs. 96.3\%) but detection of estrus at timed AI (30.9 vs. 23.6\%) was greater for CoS72 than $5 \mathrm{dCoS} 2$, and cows in estrus had increased P/AI (46.2 vs. 31.9\%). Cows in CoS72
\end{abstract}

Received October 30, 2009

Accepted March 25, 2010.

${ }^{1}$ Corresponding author: jepsantos@ufl.edu

${ }^{2}$ Authors contributed equally to the manuscript. ovulated a larger follicle and had greater concentrations of estradiol on the day of AI than cows in $5 \mathrm{dCoS} 2$, but protocol synchronization tended to increase in cows receiving the 5dCoS2. When all 933 cows were evaluated, $\mathrm{P} / \mathrm{AI}$ was greater for $5 \mathrm{dCoS} 2$ than for CoS72 (37.9 vs. $30.9 \%$ ). Similarly, when only cows with progesterone $<1 \mathrm{ng} / \mathrm{mL}$ on the day of AI were evaluated, P/AI was greater for $5 \mathrm{dCoS} 2$ than for CoS72 (39.3 vs. 33.9\%). Treatment with $\mathrm{PGF}_{2 \alpha}$ on d 5 and 6 after $\mathrm{GnRH}$ resulted in increased luteolysis and allowed for reducing the interval from GnRH to timed AI, which increased $\mathrm{P} / \mathrm{AI}$. Reducing time of follicle dominance in timed AI protocols improves fertility of lactating dairy cows.

Key words: corpus luteum regression, dairy cow, follicle dominance, timed artificial insemination

\section{INTRODUCTION}

Timed AI programs based on $\mathrm{GnRH}$ and $\mathrm{PGF}_{2 \alpha}$ to synchronize follicle wave emergence, corpus luteum (CL) regression, and ovulation have shown that cows that ovulated to the first GnRH injection were more likely to have a synchronized ovulation at the end of the protocol (Vasconcelos et al., 1999; Rutigliano et al., 2008). Furthermore, ovulation to the first GnRH of the timed AI program increased pregnancy per AI (P/AI) in lactating dairy cows (Chebel et al., 2006; Rutigliano et al., 2008). Therefore, ovulation to the first GnRH injection of the timed AI protocol can improve fertility by increasing synchronization of ovulation near AI, but it also reduces the period of follicle dominance, which might benefit fertility.

Cerri et al. (2009) recently demonstrated that cows inseminated at fixed time had equal or better quality embryos than cows inseminated on estrus when the timed AI protocol was initiated on d 6 of the estrous cycle. On the other hand, when the protocol was initiated on $\mathrm{d} 3$ of the estrous cycle, follicle turnover occurred in only $7 \%$ of the cows and embryo quality was compromised markedly. The improvement in embryo quality was attributed to a reduced period of follicle dominance in cows initiating the timed AI on d 6 of the estrous cycle. In fact, embryo quality was related 
inversely to length of follicle dominance, and a slight extension of $1.5 \mathrm{~d}$ beyond $6 \mathrm{~d}$ was sufficient to reduce the proportion of better quality embryos. The negative effect of extended follicle dominance on $\mathrm{P} / \mathrm{AI}$ is not isolated to cows submitted to timed AI protocols. Bleach et al. (2004) observed that cows inseminated following spontaneous estrus that became pregnant had a mean interval from emergence of dominant follicle to ovulation $1 \mathrm{~d}$ shorter than those that failed to become pregnant.

A limitation to manipulate the length of follicle dominance when GnRH is used is the ability of $\mathrm{PGF}_{2 \alpha}$ products to regress a newly formed CL. It is known that $\mathrm{CL}$ of cattle are refractory to $\mathrm{PGF}_{2 \alpha}$ during the first $5 \mathrm{~d}$ of the estrous cycle (Tsai and Wiltbank, 1998; Miyamoto et al., 2005). Therefore, in programs in which a new CL is induced by $\mathrm{GnRH}$, the interval to a single injection of $\mathrm{PGF}_{2 \alpha}$ to regress the new $\mathrm{CL}$ has to exceed 5 d. Recently, Bridges et al. (2008) observed increased $\mathrm{P} / \mathrm{AI}$ in beef cows by reducing the interval from GnRH to $\mathrm{PGF}_{2 \alpha}$ from 7 to $5 \mathrm{~d}$ and extending the proestrus to $3 \mathrm{~d}$ when cows were subjected to the Cosynch timed AI protocol that included a progesterone insert (CIDR) and 2 treatments with $\mathrm{PGF}_{2 \alpha}$. With the 5-d program, 2 doses of $\mathrm{PGF}_{2 \alpha}$ administered $7 \mathrm{~h}$ apart resulted in greater $\mathrm{P} / \mathrm{AI}$ compared with a single dose of either dinoprost or cloprostenol (Kasimanickam et al., 2009). The second dose may be particularly critical in cows that are presynchronized before enrolling in the timed AI protocol because of an increase in ovulation to the first $\mathrm{GnRH}$ and occurrence of a newly formed CL (Galvão et al., 2007).

It was hypothesized that reducing the interval from recruitment of a new follicular wave to induction of ovulation from 10 to $8 \mathrm{~d}$ would improve $\mathrm{P} / \mathrm{AI}$ in lactating dairy cows. Because it was hypothesized that a single injection of $\mathrm{PGF}_{2 \alpha}$ would not be very effective at regressing a newly formed CL $5 \mathrm{~d}$ after induction of ovulation, a preliminary study was designed to determine the need for a subsequent treatment with $\mathrm{PGF}_{2 \alpha}$ $24 \mathrm{~h}$ later. Therefore, our objectives were to determine the effect of reducing the interval from follicle recruitment to luteolysis and induction of ovulation on luteal regression, estradiol concentrations during proestrus, ovarian follicular responses, P/AI, and pregnancy loss in lactating dairy cows.

\section{MATERIALS AND METHODS}

Two experiments were conducted to determine the effect of reducing the period of follicle dominance on fertility of dairy cows. Experiment 1 was designed to determine whether 1 or 2 injections of $\mathrm{PGF}_{2 \alpha}$ would be sufficient to induce regression of a CL, allowing for syn- chronization of ovulation within $48 \mathrm{~h}$ of the final $\mathrm{GnRH}$ of the timed AI protocol. Experiment 2 was designed to test whether reducing the period of follicle dominance by altering the interval between the first $\mathrm{GnRH}$ injection and the $\mathrm{PGF}_{2 \alpha}$ injection would improve $\mathrm{P} / \mathrm{AI}$ in lactating dairy cows.

\section{Experiment 1: Cows, Housing, and Diets}

Lactating Holstein cows, 125 multiparous and 40 primiparous, from 2 dairy farms were assigned to the study. Within each farm, primiparous and multiparous cows were housed separately and received the same TMR to meet or exceed the nutrient requirements for a lactating Holstein cow producing $45 \mathrm{~kg}$ of milk with $3.5 \%$ fat and $3.2 \%$ true protein (NRC, 2001). Cows were fed twice daily in farm 1 and once daily in farm 2 and were milked twice daily in farm 1 and thrice daily in farm 2. Diets were formulated using the CPM-Dairy ration software (http://www.cpmdairy.net/Index.php) and, in both farms, they consisted of corn silage, alfalfa hay, alfalfa silage, steam-flaked corn, whole cottonseed, citrus pulp, almond hulls, soybean meal, expeller soybean meal, an animal-marine protein blend, minerals, and vitamins.

\section{Treatments}

Within each farm, cows were blocked by parity and randomly assigned to 1 of 3 treatments at $36 \pm 3$ DIM. All cows had their estrous cycles presynchronized with 2 i.m. injections of $500 \mu \mathrm{g}$ each of a $\mathrm{PGF}_{2 \alpha}$ analog (Estrumate, $250 \mu \mathrm{g} / \mathrm{mL}$ of cloprostenol as cloprostenol sodium, Intervet Schering Plough Animal Health Corp., Union, NJ) given $14 \mathrm{~d}$ apart starting at $36 \pm 3$ DIM. Eleven days after the second injection of $\mathrm{PGF}_{2 \alpha}$, at 61 \pm 3 DIM, cows received an i.m. injection of $100 \mu \mathrm{g}$ of $\mathrm{GnRH}$ (Cystorelin, $50 \mu \mathrm{g} / \mathrm{mL}$ of gonadorelin diacetate tetrahydrate, Merial Ltd., Duluth, GA). Cows in Cosynch-72 (CoS72, $\mathrm{n}=62)$ received an injection of $\mathrm{PGF}_{2 \alpha} 7 \mathrm{~d}$ after $\mathrm{GnRH}(68 \pm 3 \mathrm{DIM})$ and a final injection of GnRH $72 \mathrm{~h}$ after the $\mathrm{PGF}_{2 \alpha}$ at $71 \pm 3 \mathrm{DIM}$; cows in 5-d Cosynch with a single injection of $\mathrm{PGF}_{2 \alpha}$ $(5 \mathrm{dCoS} 1, \mathrm{n}=52)$ received an injection of $\mathrm{PGF}_{2 \alpha} 5$ d after GnRH (66 \pm 3 DIM) and a final injection of GnRH $72 \mathrm{~h}$ after the $\mathrm{PGF}_{2 \alpha}$ at $69 \pm 3$ DIM; cows in 5 -d Cosynch with 2 injections of $\mathrm{PGF}_{2 \alpha}\left(\mathbf{5} \mathrm{dCoS2}_{2} \mathrm{n}=51\right)$ received an injection of $\mathrm{PGF}_{2 \alpha} 5$ and $6 \mathrm{~d}$ after $\mathrm{GnRH}$ (66 and $67 \pm 3$ DIM) and a final injection of GnRH 72 $\mathrm{h}$ after the first $\mathrm{PGF}_{2 \alpha}$ at $69 \pm 3 \mathrm{DIM}$ (Figure 1).

The 2 injections of $\mathrm{PGF}_{2 \alpha}$ of the presynchronization and the first $\mathrm{GnRH}$ of the timed AI protocols were given on different days of the week for CoS72 (presynchronization on Thursdays and first GnRH on Mondays) 


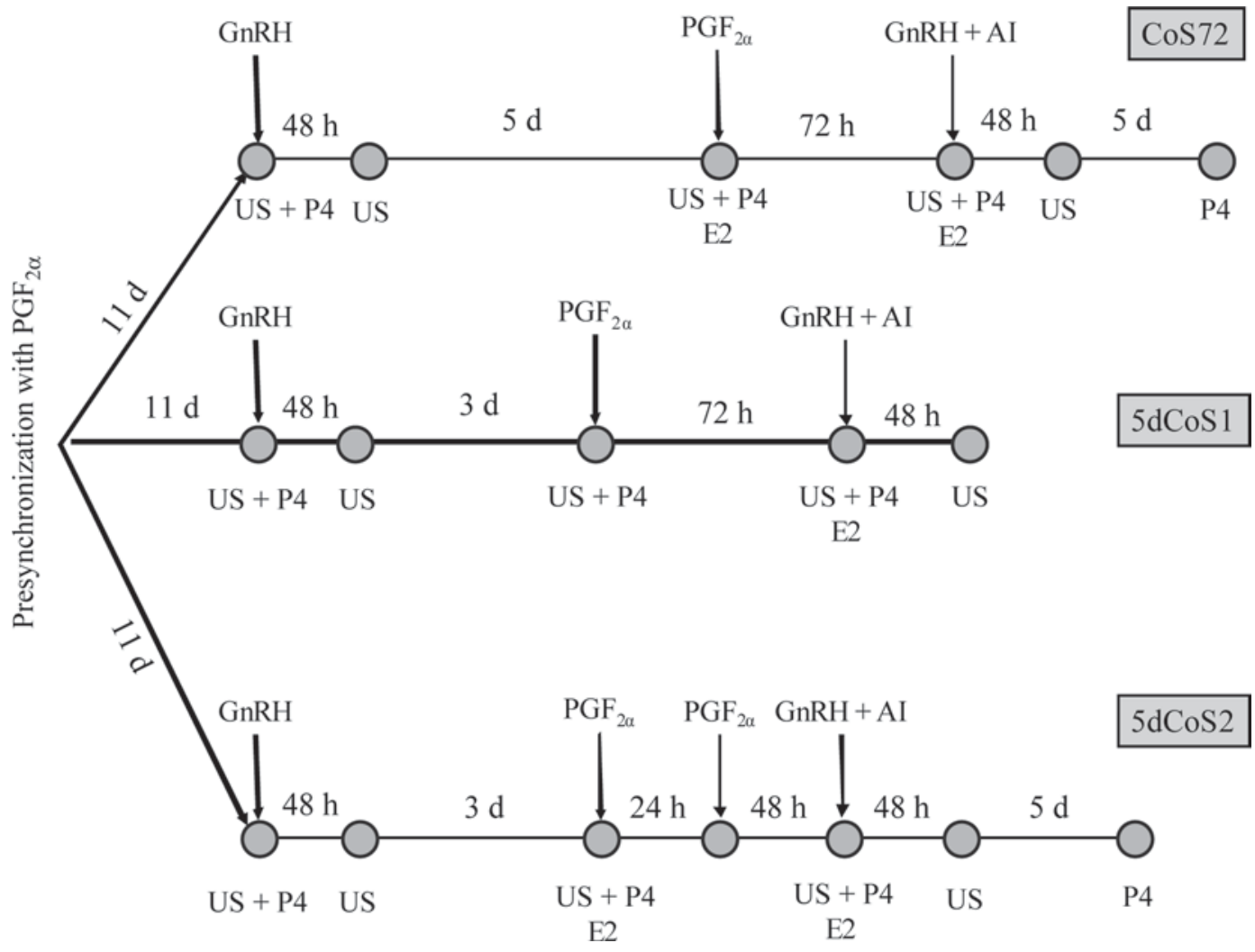

Figure 1. Diagram of activities in experiments 1 and 2. Experiment 1 had cows in all 3 treatments $(\operatorname{CoS} 72,5 \mathrm{dCoS} 1$, and $5 \mathrm{dCoS} 2 ;$ CoS72 $=\mathrm{d}$ $0 \mathrm{GnRH}$, d $7 \mathrm{PGF}_{2 \alpha}$, d $10 \mathrm{GnRH}+$ timed $\mathrm{AI} ; 5 \mathrm{dCoS}_{1}=\mathrm{d} 0 \mathrm{GnRH}$, d $5 \mathrm{PGF}_{2 \alpha}$, d $8 \mathrm{GnRH}+$ timed $\mathrm{AI} ; 5 \mathrm{dCoS} 2=\mathrm{d} 0 \mathrm{GnRH}, \mathrm{d} 5$ and $6 \mathrm{PGF}{ }_{2 \alpha}$, d $8 \mathrm{GnRH}+$ timed AI), whereas experiment 2 had cows only in CoS72 and 5dCoS2. E2 = blood sampling and analysis of estradiol in plasma of 75 cows in experiment 2; GnRH = injection of $100 \mu \mathrm{g}$ of gonadorelin; P4 = blood sampling and analysis of progesterone concentration in plasma of all cows (sample on d 7 after AI was from 232 cows in experiment 2); $\mathrm{PGF}_{2 \alpha}=$ injection of $500 \mu \mathrm{g}$ of cloprostenol; presynchronization $=2$ injections of $\mathrm{PGF}_{2 \alpha} 14 \mathrm{~d}$ apart; US = ultrasonography of the ovaries in all cows in experiment 1 and 343 cows in experiment 2.

and the 5dCoS1 and 5dCoS2 (presynchronization on Saturdays and first GnRH on Wednesdays) such that all treatments received the final $\mathrm{GnRH}$ injection of the timed AI on the same day of the week (Thursdays).

\section{Ultrasonography of Ovaries}

Ovaries were examined by transrectal ultrasonography using an ultrasound scanner (Sonovet 2000, Universal Medical System, Bedford Hills, NY) equipped with 7.5-MHz linear transducer to determine follicle and CL diameters and ovulatory responses to the GnRH injections of the timed AI protocols. Cows were scanned during the timed AI protocols on the days of the first GnRH injection, $48 \mathrm{~h}$ later on the day of the $\mathrm{PGF}_{2 \alpha}$ injection (first $\mathrm{PGF}_{2 \alpha}$ in $5 \mathrm{dCoS} 2$ ), on the day of the second GnRH injection, and $48 \mathrm{~h}$ later (Figure 1).

A map of each ovary was drawn with the position and diameter of follicles $\geq 8 \mathrm{~mm}$ in diameter and $\mathrm{CL}$, which allowed for evaluation of ovulatory responses to first and second injections of GnRH of the timed AI proto- cols and the incidence of double ovulation. Ovulation to the first GnRH was characterized by the disappearance of one or more follicles $\geq 8 \mathrm{~mm}$ in diameter within $2 \mathrm{~d}$ of injection and appearance of a newly formed CL at the $\mathrm{PGF}_{2 \alpha}$. Ovulation to the second GnRH was characterized by the disappearance of one or more follicles $\geq 8$ $\mathrm{mm}$ in diameter present on the day of the $\mathrm{GnRH}$ and absent 2 d later.

\section{Blood Sampling and Analyses of Progesterone in Plasma}

Blood was sampled from all cows by puncture of the coccygeal vein or artery into evacuated tubes containing $\mathrm{K}_{2}$ EDTA (Vacutainer, Becton Dickinson, Franklin Lakes, NJ). Blood samples were collected on the days of the injections of the first $\mathrm{GnRH}$, first $\mathrm{PGF}_{2 \alpha}$, and final GnRH of the timed AI protocols. Samples were immediately cooled by placing them on ice and they arrived at the laboratory within $6 \mathrm{~h}$ of collection. Blood tubes were centrifuged at $3,000 \times g$ for $15 \mathrm{~min}$ in a refriger- 
ated centrifuge at $5^{\circ} \mathrm{C}$ for plasma separation. Plasma samples were frozen at $-25^{\circ} \mathrm{C}$ for later analyses.

Concentrations of progesterone were analyzed in all plasma samples in duplicate by a solid-phase RIA with a commercial kit (Immulite, Siemens Healthcare Diagnostics, Flanders, NJ). The sensitivity of the assay was $0.05 \mathrm{ng} / \mathrm{mL}$ calculated at 2 standard deviations below the mean counts per minute at maximum binding. A single assay was performed with all samples, and low $(1.5 \mathrm{ng} / \mathrm{mL})$ and moderate $(2.5 \mathrm{ng} / \mathrm{mL})$ concentration samples were incorporated several times in the assay and used to calculate the intraassay CV. For the low and moderate samples, the intraassay CV were 5.10 and $4.80 \%$, respectively. Samples whose duplicate samples resulted in $\mathrm{CV}>15 \%$ were reanalyzed.

\section{Evaluation of CL Regression and Protocol Synchronization}

Luteal regression was evaluated in cows with progesterone concentration $\geq 1.0 \mathrm{ng} / \mathrm{mL}$ on the day of the injection of $\mathrm{PGF}_{2 \alpha}$. Cows with progesterone $\geq 1.0 \mathrm{ng} /$ $\mathrm{mL}$ on that day and progesterone $<1 \mathrm{ng} / \mathrm{mL} 3$ d later, on the day of the final GnRH of the synchronization protocols, were considered to have had luteal regression.

Cows were considered to have properly synchronized in response to the timed AI protocol when progesterone $\geq 1.0 \mathrm{ng} / \mathrm{mL}$ on the day of the injection of $\mathrm{PGF}_{2 \alpha}$, followed by regression of the $\mathrm{CL}$ and subsequent ovulation within $48 \mathrm{~h}$ after the final GnRH of the timed AI protocols. Cows that did not experience one or more of these criteria were considered to have not had a synchronized estrous cycle and ovulation. These criteria were selected because they are associated with increased P/AI following timed AI protocols.

\section{Milk Yield and BCS}

Body condition of all cows was scored (Ferguson et al., 1994) on the day of the first GnRH of the timed AI protocols at $62 \pm 3$ DIM. For analysis of effect of BCS on reproductive outcomes, BCS was categorized as $\leq 2.75$ or $\geq 3.00$. Yields of milk were recorded for individual cows once monthly during the official DHIA test in the first 3 mo postpartum.

\section{Experiment 2: Cows, Housing, and Diets}

Lactating Holstein cows, 281 primiparous and 652 multiparous, from the same 2 dairy farms as in experiment 1 were assigned to the study. Within each farm, cows were housed and fed as described for experiment 1.

\section{Treatments}

Cows were assigned to treatments at $36 \pm 3$ DIM. Within each farm, cows were blocked by parity and randomly assigned to 1 of 2 treatments. The treatments selected from experiment 1 were CoS72 (143 primiparous and 327 multiparous) and 5dCoS2 (138 primiparous and 325 multiparous). Cows had their estrous cycles presynchronized as described in experiment 1 , and treatments were implemented as in experiment 1 (Figure 1).

The 2 injections of $\mathrm{PGF}_{2 \alpha}$ of the presynchronization and the first $\mathrm{GnRH}$ of the timed AI protocols were given on different days of the week for CoS72 (presynchronization on Thursdays and first GnRH on Mondays) and 5dCoS2 (presynchronization on Saturdays and first GnRH on Wednesdays) such that cows in both treatments received the final GnRH injection of the timed AI on the same day of the week (Thursdays) to ensure that all AI would be performed in the same day by the same technicians in both treatments.

All cows were inseminated concurrent with the second injection of GnRH of the timed AI protocols. In farm 1 , cows were inseminated by 2 technicians, whereas in farm 2 they were inseminated by 3 technicians. All cows in farm 2 were painted with chalk on their tail heads daily after the first $\mathrm{GnRH}$ of the timed AI protocols, and removal of chalk on the day of timed AI was used as indication of estrus. All cows in both farms were inseminated on the day of scheduled timed AI. After the first timed AI, cows were observed for estrus daily and those in estrus were inseminated in the same day.

\section{Ultrasonography of Ovaries}

All cows in farm $1(\mathrm{n}=114)$ and a subset of cows in farm $2(\mathrm{n}=229)$ had their ovaries examined by transrectal ultrasonography exactly as described in experiment 1 (Figure 1).

\section{Blood Sampling and Analyses of Progesterone and Estradiol in Plasma}

Blood was sampled from all cows by puncture of the coccygeal vein or artery into evacuated tubes containing $\mathrm{K}_{2}$ EDTA (Vacutainer, Becton Dickinson) on the same days as described for experiment 1. In addition, blood was sampled from 114 CoS72 cows (44 primiparous and 70 multiparous) and $1185 \mathrm{dCoS} 2$ cows (43 primiparous and 75 multiparous) $7 \mathrm{~d}$ after timed AI. Samples were immediately cooled by placing them on ice and arrived at the laboratory within $6 \mathrm{~h}$ of collection. Blood tubes were centrifuged at $3,000 \times g$ for $15 \mathrm{~min}$ in refrigerated centrifuge at $5^{\circ} \mathrm{C}$ for plasma separation. Plasma samples were frozen at $-25^{\circ} \mathrm{C}$ for later analyses. 
Concentrations of progesterone were analyzed in all plasma samples in duplicate by a solid-phase RIA with a commercial kit (Immulite, Siemens Healthcare Diagnostics). The sensitivity of the assay was $0.05 \mathrm{ng} /$ $\mathrm{mL}$ calculated at 2 standard deviations below the mean counts per minute at maximum binding. Low (1.5 ng/ $\mathrm{mL})$ and moderate $(2.5 \mathrm{ng} / \mathrm{mL})$ concentration samples were incorporated several times in every assay and used to calculate the intra- and interassay CV. For the low sample, the intra- and interassay CV were 5.20 and $8.83 \%$, respectively, and for the moderate sample, they were 2.57 and $5.79 \%$, respectively.

Concentrations of estradiol were measured in plasma samples collected on the day of $\mathrm{PGF}_{2 \alpha}$ injection (first $\mathrm{PGF}_{2 \alpha}$ injection of $5 \mathrm{dCoS} 2$ cows) and on the day of AI from 36 CoS72 cows (13 primiparous and 23 multiparous) and $395 \mathrm{dCoS} 2$ cows (13 primiparous and 26 multiparous) by RIA according to Kirby et al. (1997). Samples were analyzed in triplicate in a single assay and the CV was $9.2 \%$. Mean sensitivity of the assay, calculated as 2 standard deviations below the mean counts per minute at maximum binding, was $0.52 \mathrm{pg} /$ $\mathrm{mL}$.

\section{Evaluation of CL Regression and Protocol Synchronization}

Luteal regression and synchronization to the timed AI protocols were evaluated exactly as described in experiment 1. Regression of the CL for cows that ovulated to the first GnRH of the timed AI protocols and synchronization to the timed AI protocols were analyzed only in the 343 cows that had their ovaries mapped by ultrasonography.

\section{Pregnancy Diagnoses and P/Al and Pregnancy Loss}

Pregnancy was diagnosed by transrectal palpation of the uterus $38 \mathrm{~d}$ after timed AI. Presence of an embryonic vesicle was used as a determinant of pregnancy. Pregnant cows on d 38 were re-examined for pregnancy 4 wk later, on gestation d 66. Pregnancy per AI was calculated on d 38 and 66. Pregnancy loss between 38 and $66 \mathrm{~d}$ of gestation also was calculated.

\section{Body Condition Scoring and Milk Yield}

Body condition of all cows was scored (Ferguson et al., 1994) on the day of the first GnRH injection of the timed AI protocols at $61 \pm 3$ DIM. For statistical analysis, BCS was categorized as $\leq 2.75$ or $\geq 3.00$. Yields of milk were recorded for individual cows once monthly during the official DHIA test in the first $3 \mathrm{mo}$ postpartum.

\section{Experimental Design and Statistical Analyses}

The study was a randomized block design. In experiment 1, within farm, cows were blocked by parity and, within each block, randomly assigned to 1 of the 3 treatments. In experiment 2, a weekly cohort of cows within farm was blocked by parity and randomly assigned to 1 of the 2 treatments.

The baseline $\mathrm{P} / \mathrm{AI}$ at first $\mathrm{AI}$ in farms 1 and 2 were 33 and $35 \%$, respectively, at the beginning of the study using CoS72. Considering the average P/AI of $34 \%$ for both dairy herds, to have at least a $95 \%$ chance $(P \leq$ 0.05 ) of detecting a 5-percentage-unit increase in $\mathrm{P} / \mathrm{AI}$ (e.g., 34 vs. $39 \%$ ) with $90 \%$ protection against a type II error, a total of 966 cows was calculated to be needed using a one-tailed test.

Binary responses such as ovulation to the first and second GnRH injections of the timed AI protocols, progesterone status ( $\geq 1 \mathrm{ng} / \mathrm{mL}$ or $<1 \mathrm{ng} / \mathrm{mL}$ ) during the timed AI protocol, CL regression, detection of estrus at timed AI, re-insemination before d 18 after timed AI, $\mathrm{P} / \mathrm{AI}$, and pregnancy loss were analyzed by logistic regression using the LOGISTIC procedure of SAS version 9.2 (SAS Institute Inc., Cary, NC). All models included the effects of treatment, parity, farm, BCS, milk yield, and interactions of treatment and parity and treatment and farm. Additional covariates and their interactions with treatment were added to the models if univariate analyses identified them as significant $(P<0.10)$. Detection of estrus at AI was performed in only one farm; therefore, the effect of farm and its interaction with treatment was not included in the model.

Continuous variables such as diameter of ovarian follicles and concentrations of progesterone and estradiol were analyzed by ANOVA using the GLM procedure of SAS. The models included the effects of treatment, farm, parity, milk yield, BCS, progesterone status on the day of the first GnRH of the timed AI protocols, ovulation to the first GnRH of the timed AI protocols, and interactions of treatment and farm, treatment and parity, treatment and progesterone status, and treatment and ovulation to the first GnRH of the timed AI protocols. Because estradiol was measured in plasma only in farm 2, the effect of farm and interaction between treatment and farm were not included in the statistical model.

Receiver operating characteristic (ROC) curve was used to determine the optimum concentration of progesterone at timed AI to result in highest sensitivity and specificity to predict pregnancy in dairy cows. Effects of the diameter of the largest follicle at timed AI on probability of ovulation and of progesterone at AI on pregnancy were modeled using logistic regression curves with the intercept and the coefficient estimates 
Table 1. Effect of reducing the period of follicle dominance on ovarian responses and luteal regression of dairy cows during the timed AI protocols (experiment 1 )

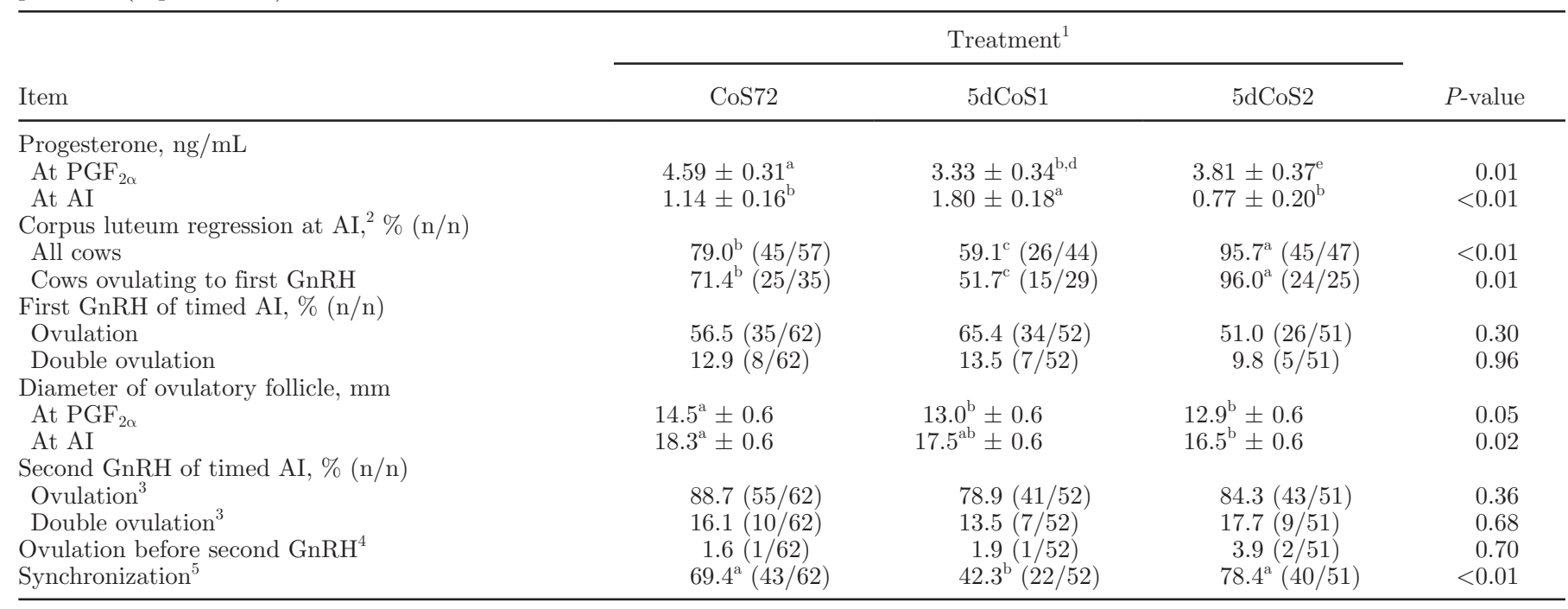

${ }^{\mathrm{a}-\mathrm{c}}$ Values with different superscripts in the same row differ $(P<0.05)$.

${ }^{\mathrm{d}, \mathrm{e}}$ Values with different superscripts in the same row differ $(P=0.06)$.

${ }^{1}$ All cows were presynchronized with 2 injections of $\mathrm{PGF}_{2 \alpha}$ given $14 \mathrm{~d}$ apart, and the timed AI protocols were initiated $11 \mathrm{~d}$ later. CoS72 $=\mathrm{d} 0$

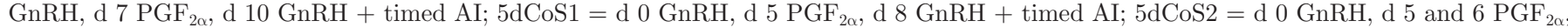
d $8 \mathrm{GnRH}+$ timed AI.

${ }^{2}$ Cows with progesterone $\geq 1 \mathrm{ng} / \mathrm{mL}$ at $\mathrm{PGF}_{2 \alpha}$ and $<1 \mathrm{ng} / \mathrm{mL}$ at $\mathrm{AI}$.

${ }^{3}$ Ovulation within the first $48 \mathrm{~h}$ of the final GnRH of the timed AI protocols.

${ }^{4}$ Ovulation between the injections of $\mathrm{PGF}_{2 \alpha}$ and the $2 \mathrm{nd} \mathrm{GnRH}$ of the timed AI protocols.

${ }^{5}$ Cows that regressed their corpus luteum (progesterone $\geq 1 \mathrm{ng} / \mathrm{mL}$ at $\mathrm{PGF}_{2 \alpha}$ and $<1 \mathrm{ng} / \mathrm{mL}$ at $\mathrm{AI}$ ) and ovulated within $48 \mathrm{~h}$ of timed AI.

from the analysis applied to the formula $P=1 /\left[1+\left(e^{a+b_{1} X_{1}+a+b_{2} X_{2}+\ldots}\right)\right]$. Treatment differences with $P \leq 0.05$ were considered significant and those with $0.05<P \leq 0.10$ were considered as a tendency.

\section{RESULTS}

\section{Experiment 1}

The average BCS and milk yield for cows in CoS72 $(2.84 \pm 0.05$ and $36.3 \pm 0.8 \mathrm{~kg} / \mathrm{d}), 5 \mathrm{dCoS} 1(2.77 \pm 0.05$ and $37.8 \pm 0.9 \mathrm{~kg} / \mathrm{d})$, and $5 \mathrm{dCoS} 2(2.80 \pm 0.06$ and $37.0 \pm 1.0 \mathrm{~kg} / \mathrm{d})$ did not differ $(P>0.10)$ among treatments. The proportion of cows with progesterone $\geq 1.0$ $\mathrm{ng} / \mathrm{mL}$ tended $(P=0.10)$ to differ among treatments because fewer CoS72 and 5dCoS1 than 5dCoS2 cows had an active CL on the day of the first GnRH (71.0 vs. 69.2 vs. $86.3 \%$, respectively).

Ovulation and double ovulation to the first $\mathrm{GnRH}$ injection of the timed AI protocols were not different among treatments (Table 1). Progesterone concentration on the day of the $\mathrm{PGF}_{2 \alpha}$ injection of the timed AI differed $(P=0.01)$, and it was greater for cows in CoS72 than $5 \mathrm{dCoS} 1$ or $5 \mathrm{dCoS} 2$ (Table 1). On the day of the second $\mathrm{GnRH}$, however, progesterone concentra- tions had decreased and they were less for CoS72 and $5 \mathrm{dCoS} 2$ than for $5 \mathrm{dCoS} 1$. The changes in progesterone concentrations were the result of differences $(P<0.01)$ in CL regression among treatments. Cows receiving a single injection of $\mathrm{PGF}_{2 \alpha} 5 \mathrm{~d}$ after $\mathrm{GnRH}$ had less CL regression than cows receiving a single injection on $\mathrm{d} 7$ or 2 injections of $\mathrm{PGF}_{2 \alpha}$ on $\mathrm{d} 5$ and 6 after GnRH (Table 1). These differences in CL regression were observed regardless of ovulation to the first $\mathrm{GnRH}$ injection of the timed AI protocols (Table 1). Nevertheless, cows that ovulated to the first GnRH tended $(P=0.10)$ to have less CL regression than those that did not ovulate in response to $\mathrm{GnRH}$ [73.0 vs. 86.4\%; adjusted odds ratio $(\mathbf{A O R})=0.46,95 \% \mathrm{CI}=0.18$ to 1.18$]$.

As expected, the diameter of the ovulatory follicle on the days of the injections of $\mathrm{PGF}_{2 \alpha}$ and second $\mathrm{GnRH}$ differed $(P<0.05)$ among treatments (Table 1$)$. On the day of $\mathrm{PGF}_{2 \alpha}$, cows in CoS72 had larger ovulatory follicle diameters than cows in the 5-d programs (Table 1). However, on the day of AI, diameter of the ovulatory follicle differed $(P<0.01)$ only between CoS72 and $5 \mathrm{dCoS2}$ (Table 1). Ovulation or double ovulation within $48 \mathrm{~h}$ of the second GnRH of the timed AI protocol did not differ among treatments and they averaged 84.2 and $15.8 \%$, respectively (Table 1 ). Similarly, ovulation before AI did not differ among treatments and affected 
only $2.4 \%$ of the cows. When protocol synchronization was evaluated, CoS72 and 5dCoS2 resulted in similar responses, but they were both greater $(P<0.01)$ than $5 \mathrm{dCoS} 1$.

\section{Experiment 2}

Because of differences in CL regression and synchronization observed between cows receiving the 5-d Cosynch with 1 versus 2 injections of $\mathrm{PGF}_{2 \alpha}, 5 \mathrm{dCoS} 2$ was selected to evaluate the effect of altering the interval between $\mathrm{GnRH}$ and $\mathrm{PGF}_{2 \alpha}$, to reduce the period of follicle dominance in timed AI protocols, on fertility responses of dairy cows.

The mean and median lactation number $(2.14 \pm 0.05$ and 2) and BCS (2.88 \pm 0.02 and 2.88) in experiment 2 were exactly the same for CoS72 and 5dCoS2. Milk yield in the first 3 mo postpartum did not differ between treatments and averaged $37.4 \pm 0.4 \mathrm{~kg} / \mathrm{d}$. The proportion of cows with progesterone $\geq 1.0 \mathrm{ng} / \mathrm{mL}$ on the day of the first GnRH of the timed AI protocols did not differ and they were 70.2 and $66.3 \%$ of the CoS72 and $5 \mathrm{~d} \operatorname{Cos} 2$, respectively.

\section{Ovarian Responses to Treatments}

Ovulation to the first $\mathrm{GnRH}$ of the timed AI protocol did not differ between treatments and averaged $66.4 \%$ (Table 2). Progesterone concentrations on the days of the $\mathrm{PGF}_{2 \alpha}$ injection and $\mathrm{AI}$ were greater $(P<0.04)$ for cows in CoS72 than for those in $5 \mathrm{dCos} 2$. Nonetheless, concentrations did not differ between treatments on $\mathrm{d} 7$ after timed AI. Administering 2 injections of $\mathrm{PGF}_{2 \alpha}$ on d 5 and 6 after $\mathrm{GnRH}$ increased $(P<0.01)$ CL regression compared with a single $\mathrm{PGF}_{2 \alpha}$ injection on $\mathrm{d} 7$ after $\mathrm{GnRH}$, and this response was observed when evaluating all cows or only cows that ovulated to the first $\mathrm{GnRH}$ injection of the timed AI protocols. A ROC curve was generated to determine the progesterone concentration at AI with highest accuracy to predict d 38 pregnancy and nonpregnancy (Figure 2). The concentration that resulted in the highest combined sensitivity $(89.7 \%$; $95 \% \mathrm{CI}=85.8$ to 92.8$)$ and specificity $(37.3 \%$; $95 \% \mathrm{CI}$ $=33.4$ to 41.3 ) was $0.24 \mathrm{ng} / \mathrm{mL}$. This indicates that $89.7 \%$ of the pregnant cows had progesterone $\leq 0.24$ $\mathrm{ng} / \mathrm{mL}$, whereas $37.3 \%$ of the nonpregnant cows had progesterone concentration $>0.24 \mathrm{ng} / \mathrm{mL}$. At this cutoff concentration, the area under the ROC curve was $0.64(95 \% \mathrm{CI}=0.60$ to $0.67 ; P=0.0001)$. The proportion of cows with progesterone $\leq 0.24 \mathrm{ng} / \mathrm{mL}$ did not differ between treatments when all cows or only cows ovulating to the first $\mathrm{GnRH}$ of the timed AI protocols were considered (Table 2).
The concentration of estradiol on the day of $\mathrm{PGF}_{2 \alpha}$ injection did not differ between treatments, but it was greater $(P=0.02)$ for CoS72 than for $5 \mathrm{dCoS} 2$ on the day of AI (Table 2). The proportion of cows ovulating or having double ovulation in the first $48 \mathrm{~h}$ after the second GnRH injection of the timed AI protocols did not differ between treatments in spite of changes in plasma estradiol concentrations and follicular diameter on the day of AI (Table 2). As in experiment 1, the proportion of cows ovulating before the second $\mathrm{GnRH}$ was small $(2.6 \%)$ and did not differ between treatments. The proportion of cows that had their estrous cycle synchronized by the timed AI protocols tended $(P=$ $0.07)$ to be greater for $5 \mathrm{dCoS} 2$ than for CoS72.

Ovulation to the second GnRH of the timed AI protocol was influenced by progesterone status on the day of the first $\mathrm{GnRH}$ of the protocols, ovulation to the first $\mathrm{GnRH}$ of the protocols, and follicle diameter on the day of AI (Figure 3). For cyclic cows that ovulated to the first GnRH, the probability of ovulation to the second $\mathrm{GnRH}$ increased as the diameter of the largest follicle increased up to $12 \mathrm{~mm}$ and then reached a plateau with further increases in follicle diameter. On the other hand, for cows that were cyclic but did not ovulate to the first GnRH or for cows that had progesterone $<1.0$ $\mathrm{ng} / \mathrm{mL}$ but ovulated to the first $\mathrm{GnRH}$, ovulation to the second GnRH increased with follicle diameter up to $15 \mathrm{~mm}$. Finally, for cows with progesterone $<1.0 \mathrm{ng} /$ $\mathrm{mL}$ that did not ovulate to the first GnRH, maximum ovulation was only observed when follicle diameter reached $18 \mathrm{~mm}$.

\section{Fertility Responses in All Cows}

The proportion of cows in estrus based on removal of tail chalk on the day of timed AI was greater $(P<$ 0.01 ) for CoS72 than for $5 \mathrm{dCoS} 2$ (Table 3 ). The proportion of nonpregnant cows re-inseminated before 18 $\mathrm{d}$ of the first timed AI was not affected by treatment and averaged 7.6 and $5.6 \%$ among all cows and among synchronized cows, respectively (Table 3 ).

Pregnancies per AI were greater $(P \leq 0.05)$ for cows in $5 \mathrm{dCoS} 2$ than in CoS72 on both d 38 and 66 after timed AI (Table 3). Pregnancy loss between 38 and $66 \mathrm{~d}$ after AI did not differ between treatments. Cows with high $(\geq 1 \mathrm{ng} / \mathrm{mL})$ progesterone on the day of the first GnRH of the timed AI had greater $(P=0.01) \mathrm{P} /$ AI than those with low $(<1 \mathrm{ng} / \mathrm{mL})$ progesterone. Nevertheless, an interaction $(P=0.03)$ between treatment and progesterone status on the day of the first $\mathrm{GnRH}$ was observed. For cows with progesterone $\geq 1.0 \mathrm{ng} / \mathrm{mL}$ on the day of the first GnRH, treatment had a small positive effect on $\mathrm{P} / \mathrm{AI}(5 \mathrm{dCoS} 2=38.1$ vs. $\mathrm{CoS} 72=$ 
Table 2. Effect of reducing the period of follicle dominance on ovarian responses and progesterone and estradiol concentrations of dairy cows during the timed AI protocols (experiment 2)

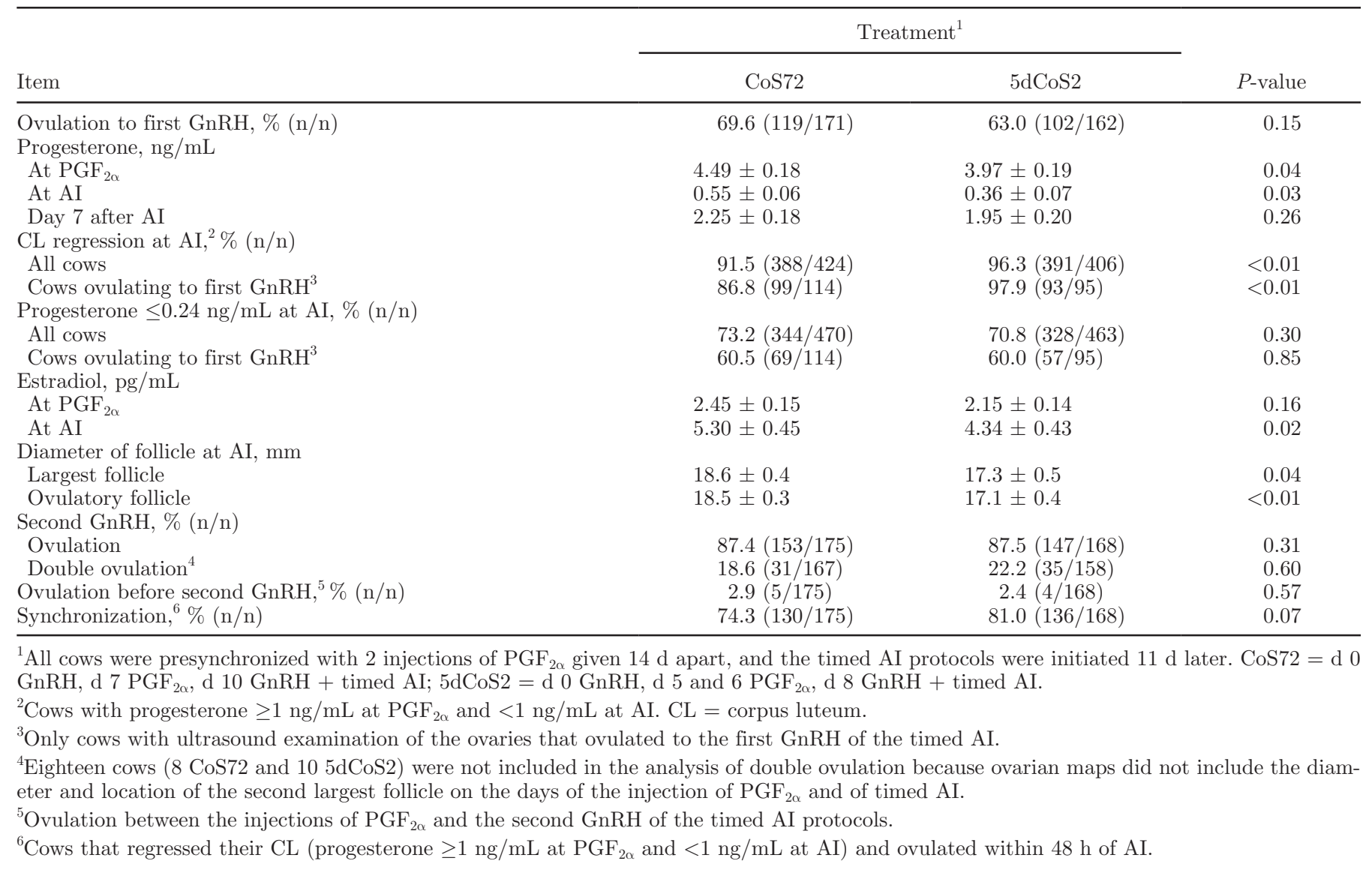

$34.8 \%$ ); however, for cows with progesterone $<1.0 \mathrm{ng} /$ $\mathrm{mL}$ on the day of the first $\mathrm{GnRH}$, those inseminated following $5 \mathrm{dCoS} 2$ had substantially greater P/AI than CoS72 cows (37.4 vs. 21.7\%). Pregnancy per AI was also influenced by farm $(P<0.01)$, BCS $(P<0.01)$, and progesterone status $(P<0.01)$ on the day of the $\mathrm{PGF}_{2 \alpha}$ of the timed AI protocols. Cows with BCS $>2.75$ had greater $\mathrm{P} / \mathrm{AI}$ than those with $\mathrm{BCS} \leq 2.75$ (39.9 vs. $28.4 \%$ ). Similarly, cows with progesterone $\geq 1.0 \mathrm{ng} / \mathrm{mL}$ on the day of the $\mathrm{PGF}_{2 \alpha}$ of the timed AI protocol had greater $\mathrm{P} / \mathrm{AI}$ than those with $<1.0 \mathrm{ng} / \mathrm{mL}$ (36.5 vs. $17.5 \%)$. Although $0.24 \mathrm{ng} / \mathrm{mL}$ was selected as the value with highest accuracy (highest combined sensitivity and specificity) to determine pregnancy and nonpregnancy statuses, $\mathrm{P} / \mathrm{AI}$ decreased $(P<0.001)$ as progesterone concentration at $\mathrm{AI}$ increased.

Two additional analyses were performed, the first with the 814 cows in farm 2 to determine the effect of estrus on $\mathrm{P} / \mathrm{AI}$. Cows that displayed estrus on the day of AI had greater $(P<0.001) \mathrm{P} / \mathrm{AI}$ on $\mathrm{d} 38(46.2$ vs. $31.9 \% ; \mathrm{AOR}=2.04 ; 95 \% \mathrm{CI}=1.46$ to 2.84$)$ and 66 $(43.0$ vs. $30.2 \% ; \mathrm{AOR}=1.90 ; 95 \% \mathrm{CI}=1.36$ to 2.66$)$ after timed AI. The second analysis was performed with the 343 cows evaluated by ultrasonography. Ovulation to the first $\mathrm{GnRH}$ of the timed AI protocols increased $(P=0.03) \mathrm{P} / \mathrm{AI}(35.2$ vs. $23.2 \%$; $\mathrm{AOR}=$ $1.80 ; 95 \% \mathrm{CI}=1.05$ to 3.09$)$ on $\mathrm{d} 38$ after insemination. Interestingly, $\mathrm{P} / \mathrm{AI}$ was greater $(P<0.01)$ in cows receiving the $5 \mathrm{dCoS} 2$ compared with $\mathrm{CoS} 72$ regardless of whether they ovulated (42.2 vs. $29.1 \%)$ or did not ovulate (33.3 vs. $11.5 \%$ ) to the first $\mathrm{GnRH}$ of the timed AI protocols.

\section{Fertility Responses in Cows with Progesterone $<1 \mathrm{ng} / \mathrm{mL}$ on the Day of Timed Al}

Treatment with $\mathrm{PGF}_{2 \alpha}$ on d 5 and 6 after $\mathrm{GnRH}$ resulted in greater CL regression than did single treatment with $\mathrm{PGF}_{2 \alpha}$ on d 7 after GnRH. Furthermore, progesterone concentration at $\mathrm{AI}$ influenced $\mathrm{P} / \mathrm{AI}$. Because the original hypothesis of the study was that reducing the period of follicle dominance by altering the interval between $\mathrm{GnRH}$ and $\mathrm{PGF}_{2 \alpha}$ would improve $\mathrm{P} /$ AI, analyses of the data with only cows that had pro- 


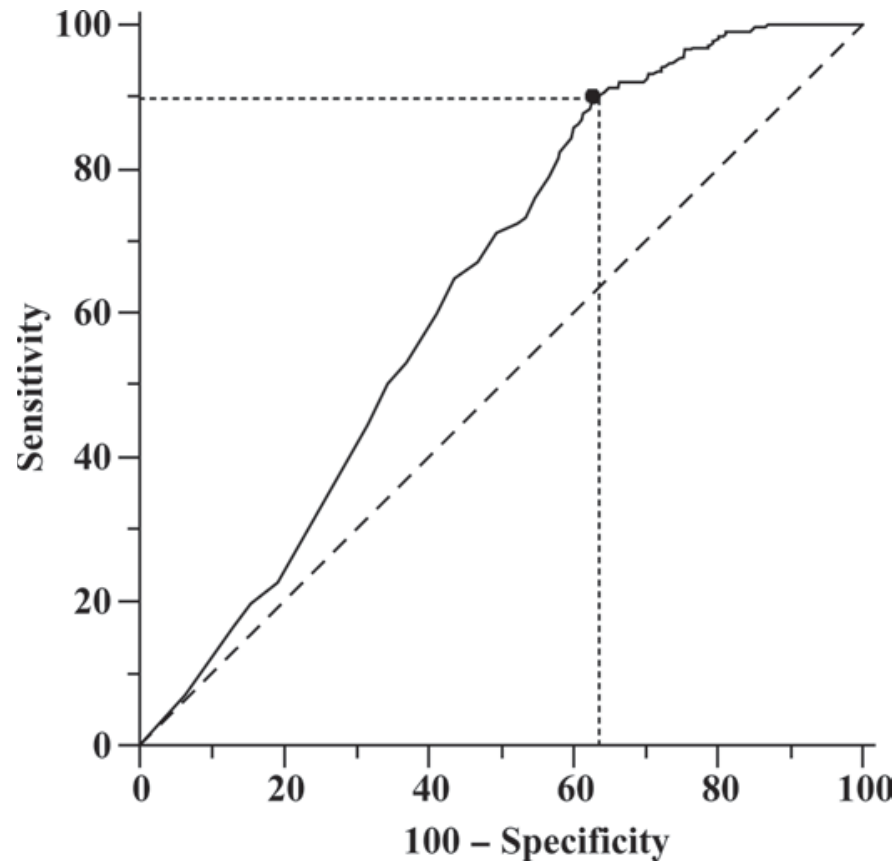

Figure 2. Receiver operating characteristic curve for the concentration of progesterone at AI that predicts pregnancy on $\mathrm{d} 38$ with the highest accuracy. Progesterone concentration of $0.24 \mathrm{ng} / \mathrm{mL}$ (dot in the curve) best predicted pregnancy. At progesterone concentration of $0.24 \mathrm{ng} / \mathrm{mL}$, sensitivity was $89.7 \%(95 \% \mathrm{CI}=85.8$ to 92.8$)$ and specificity was $37.3 \%$ (95\% CI $=33.4$ to 41.3 ). Area under the curve was $0.64(95 \% \mathrm{CI}=0.60$ to $0.67 ; P=0.0001)$. gesterone $<1 \mathrm{ng} / \mathrm{mL}$ on the day of $\mathrm{AI}$ were performed. This eliminates the potential of 2 injections of $\mathrm{PGF}_{2 \alpha}$ to improve P/AI because of better CL regression.

Similar to the results with all cows, the proportion of cows in estrus on the day of timed AI was greater $(P<0.01)$ for CoS72 than for 5dCoS2 (Table 4). Reinsemination of nonpregnant cows before $\mathrm{d} 18$ was not influenced by treatment. The $\mathrm{P} / \mathrm{AI}$ evaluated on $\mathrm{d} 38$ or 66 after the timed AI increased $(P=0.02)$ in cows synchronized with $5 \mathrm{dCoS} 2$ compared with cows synchronized with CoS72, but pregnancy loss in the first $66 \mathrm{~d}$ of gestation was not affected by treatment.

\section{DISCUSSION}

Improvements in $\mathrm{P} / \mathrm{AI}$ to timed $\mathrm{AI}$ protocols require that cows respond to each hormonal treatment, which should be applied based on physiological principles. The objective of the current study was to modify a commonly used timed AI program to determine whether reducing the period of ovulatory follicle dominance by shortening the interval from follicle recruitment to luteal regression and induced ovulation would improve P/AI of dairy cows. Cows receiving the $5 \mathrm{dCoS} 2$ had greater $\mathrm{P} / \mathrm{AI}$ on d 38 and 66 after insemination compared with those receiving CoS72. Because CL regression was also improved in 5dCoS2 cows and progesterone concentra-

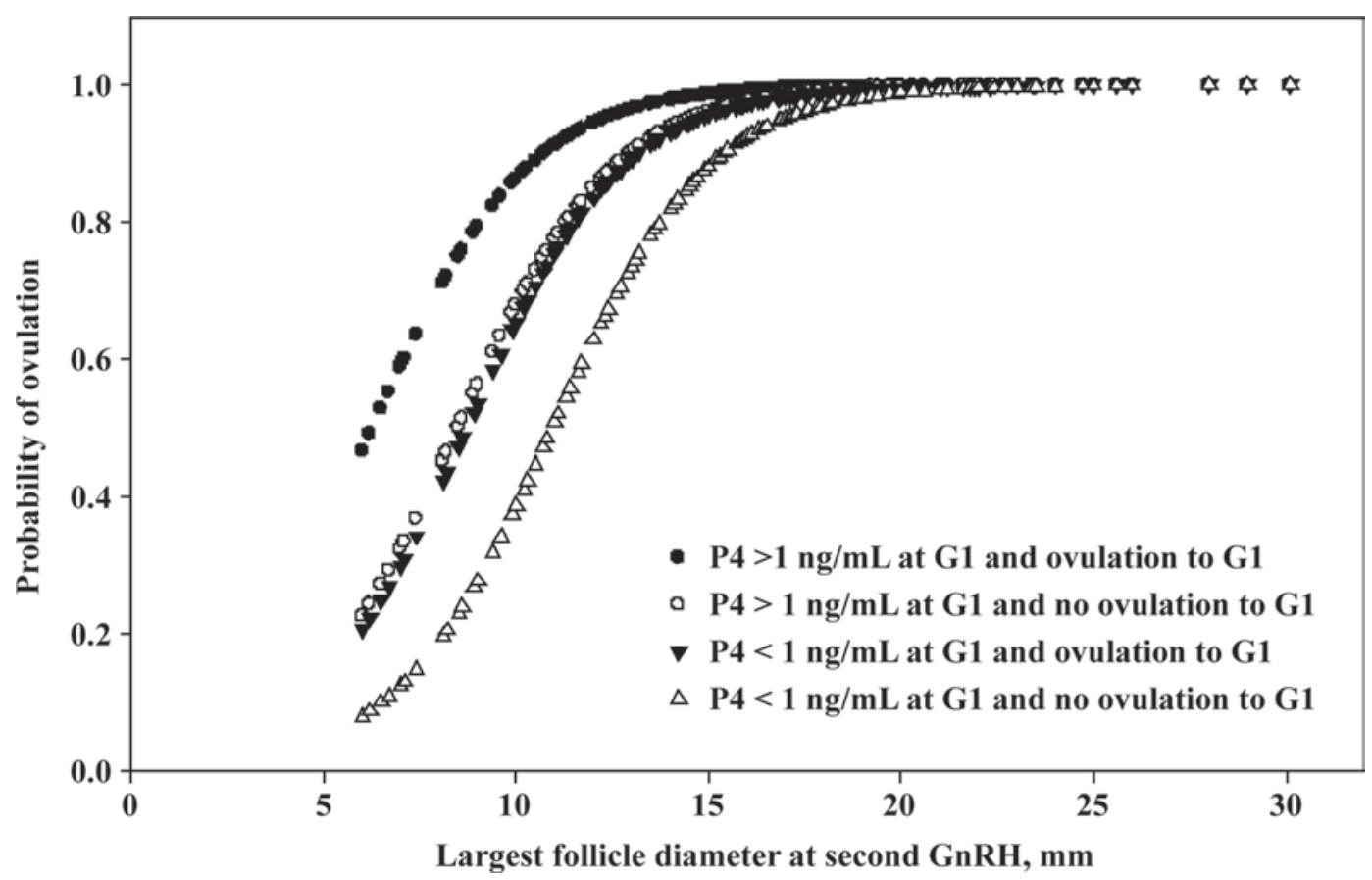

Figure 3. Probability of ovulation within $48 \mathrm{~h}$ of the second $\mathrm{GnRH}$ of the timed AI protocols according to the diameter of the largest follicle on the day of the last GnRH injection in cows of different progesterone status $(\geq 1.0 \mathrm{ng} / \mathrm{mL} ;<1.0 \mathrm{ng} / \mathrm{mL})$ on the day of the first GnRH injection (G1) and cows that did or did not ovulate to G1. Effects of treatment $(P=0.31)$, diameter of the largest follicle $(P=0.002)$, progesterone status at $\mathrm{G} 1(P=0.002)$, and ovulation to $\mathrm{G} 1(P<0.001)$. 
Table 3. Effect of reducing the period of follicle dominance on fertility responses of dairy cows (experiment 2)

\begin{tabular}{|c|c|c|c|c|}
\hline Item & \multicolumn{2}{|c|}{ Treatment $^{1}$} & $\operatorname{AOR}^{2}(95 \% \mathrm{CI})$ & $P$-value \\
\hline Estrus at timed $\mathrm{AI}^{3} \%(\mathrm{n} / \mathrm{n})$ & $30.9(126 / 408)$ & $23.6(97 / 411)$ & $0.61(0.44-0.84)$ & $<0.01$ \\
\hline $\begin{array}{l}\text { All cows } \\
\text { Synchronized cows }\end{array}$ & $\begin{array}{l}9.0(29 / 322) \\
3.5(3 / 86)\end{array}$ & $\begin{array}{l}5.9(17 / 287) \\
8.1(6 / 74)\end{array}$ & $\begin{array}{l}0.75(0.38-1.46) \\
2.1(0.68-12.62)\end{array}$ & $\begin{array}{l}0.40 \\
0.15\end{array}$ \\
\hline \multicolumn{5}{|l|}{ Pregnant, \% (n/n) } \\
\hline
\end{tabular}

${ }^{1}$ All cows were presynchronized with 2 injections of $\mathrm{PGF}_{2 \alpha}$ given $14 \mathrm{~d}$ apart, and the timed AI protocols were initiated $11 \mathrm{~d}$ later. CoS72 $=\mathrm{d} 0$ GnRH, d $7 \mathrm{PGF}_{2 \alpha}$, d $10 \mathrm{GnRH}+$ timed $\mathrm{AI} ; 5 \mathrm{dCoS} 2=\mathrm{d} 0 \mathrm{GnRH}, \mathrm{d} 5$ and $6 \mathrm{PGF}_{2 \alpha}$, d $8 \mathrm{GnRH}+$ timed AI.

${ }^{2} \mathrm{AOR}=$ adjusted odds ratio; CoS72 is the reference for comparison.

${ }^{3}$ Only cows in dairy 2 were evaluated for estrus based on removal of tail chalk at timed AI.

${ }^{4}$ Nonpregnant cows on d 38 after timed AI that were re-inseminated before d 18.

${ }^{5}$ Nonpregnant cows on $\mathrm{d} 38$ from those that were evaluated by ultrasonography and had a synchronized ovulation (progesterone $\geq 1 \mathrm{ng} / \mathrm{mL}$ at $\mathrm{PGF}_{2 \alpha}$ and $<1 \mathrm{ng} / \mathrm{mL}$ at $\mathrm{AI}$ and ovulation within $48 \mathrm{~h}$ of $\left.\mathrm{AI}\right)$.

tion on the day of AI influenced the risk of pregnancy, additional analyses were performed using only cows with plasma progesterone concentration $<1.0 \mathrm{ng} / \mathrm{mL}$ on the day of AI to validate our initial hypothesis. Indeed, when only cows with a regressed CL were used, $\mathrm{P} / \mathrm{AI}$ was also greater for $5 \mathrm{dCoS} 2$ than for CoS72 cows on d 38 and 66 after timed AI. This confirms our initial hypothesis that reducing the period of ovulatory follicle dominance by $2 \mathrm{~d}$ in a timed AI protocol that would normally last $10 \mathrm{~d}$ benefits reproductive performance of dairy cows. To further clarify this, pregnancy data from the 343 cows evaluated for ovulation to first $\mathrm{GnRH}$ in experiment 2 were analyzed. Cows in $5 \mathrm{dCoS} 2$ had greater $(P=0.003) \mathrm{P} / \mathrm{AI}(\mathrm{AOR}=2.13 ; 95 \% \mathrm{CI}=1.30$ to 3.48) regardless of ovulation to the first GnRH. For those that ovulated, P/AI were $29.1 \%$ and $42.2 \%$ for CoS72 and 5dCoS2, respectively; for cows that did not ovulate to the first GnRH, P/AI were $11.5 \%$ for CoS72 and $33.3 \%$ for $5 \mathrm{dCoS} 2$.
Bridges et al. (2008) recently completed a series of experiments with beef cattle evaluating the effect of reducing the interval from $\mathrm{GnRH}$ to $\mathrm{PGF}_{2 \alpha}$ from 7 to $5 \mathrm{~d}$ in estrous and ovulation synchronization protocols with CIDR and used 2 injections of $\mathrm{PGF}_{2 \alpha}$. In their first experiment with beef cows synchronized with 5 or $7 \mathrm{~d} \mathrm{GnRH}$ to $\mathrm{PGF}_{2 \alpha}$ programs, estrous response, interval to estrus, and $\mathrm{P} / \mathrm{AI}$ were similar between treatments. In experiment 2, when beef cows received the final GnRH and timed AI of the Cosynch + CIDR protocol at $60 \mathrm{~h}$ after induced luteolysis, reducing the interval between the first $\mathrm{GnRH}$ and $\mathrm{PGF}_{2 \alpha}$ also had no effect on P/AI. Finally, when cows received timed AI following the 5 or $7 \mathrm{~d}$ Cosynch + CIDR programs with final $\mathrm{GnRH}$ and timed AI performed at 72 and $60 \mathrm{~h}$ after $\mathrm{PGF}_{2 \alpha}$-induced luteolysis, respectively, the 5 -d program improved fertility. As in the current study, the 5-d program also required 2 injections of $\mathrm{PGF}_{2 \alpha}$ to achieve increased P/AI (Kasimanickam et al., 2009).

Table 4. Effect of reducing the period of follicle dominance on fertility responses of dairy cows with progesterone $<1 \mathrm{ng} / \mathrm{mL}$ at timed $\mathrm{AI}$ (experiment 2)

\begin{tabular}{|c|c|c|c|c|}
\hline Item & \multicolumn{2}{|c|}{ Treatment $^{1}$} & $\mathrm{AOR}^{2}(95 \% \mathrm{CI})$ & $P$-value \\
\hline Estrus at timed $\mathrm{AI},{ }^{3} \%(\mathrm{n} / \mathrm{n})$ & $32.4(121 / 373)$ & $24.2(96 / 396)$ & $0.61(0.44-0.85)$ & $<0.01$ \\
\hline \multicolumn{5}{|l|}{ Pregnant, \% (n/n) } \\
\hline Day 38 & $33.9(144 / 425)$ & $39.3(175 / 445)$ & $1.93(1.05-2.38)$ & 0.02 \\
\hline Day 66 & $32.5(138 / 425)$ & $36.7(163 / 444)$ & $1.91(1.04-2.30)$ & 0.02 \\
\hline
\end{tabular}

${ }^{1}$ All cows were presynchronized with 2 injections of $\mathrm{PGF}_{2 \alpha}$ given $14 \mathrm{~d}$ apart, and the timed AI protocols were initiated $11 \mathrm{~d}$ later. CoS72 $=\mathrm{d} 0$ $\mathrm{GnRH}$, d $7 \mathrm{PGF}_{2 \alpha}$, d $10 \mathrm{GnRH}+$ timed $\mathrm{AI} ; 5 \mathrm{dCoS} 2=\mathrm{d} 0 \mathrm{GnRH}$, d 5 and $6 \mathrm{PGF}_{2 \alpha}$, d $8 \mathrm{GnRH}+$ timed AI.

${ }^{2} \mathrm{AOR}=$ adjusted odds ratio; CoS72 is the reference for comparison.

${ }^{3}$ Only cows in dairy 2 were evaluated for signs of estrus based on removal of tail chalk at timed AI.

${ }^{4}$ Nonpregnant cows on d 38 after timed AI that were re-inseminated before d 18 . 
The benefits to $\mathrm{P} / \mathrm{AI}$ achieved with reducing the period of follicle dominance have been observed in cows displaying spontaneous estrus. Bleach et al. (2004) observed increased $\mathrm{P} / \mathrm{AI}$ in cows in which the duration of development of the ovulatory follicle was spontaneously shorter. The interval from follicle emergence to estrus was $3.5 \mathrm{~d}$ longer for cows with 2 follicular waves than for those with 3 follicular waves (Bleach et al., 2004), and cows in which the ovulatory follicle originated from the third follicular wave had greater $\mathrm{P} / \mathrm{AI}$ than cows in which the ovulatory follicle originated from the second follicular wave (Townson et al., 2002). A 1.5-d extension in the length of follicle dominance was sufficient to alter embryo quality in lactating dairy cows (Cerri et al., 2009). Therefore, the improved P/AI observed in the current study with shorter duration of follicle dominance is likely associated with improved embryo quality in lactating dairy cows. These findings reinforce those of others that showed better P/AI in beef cows subjected to a timed AI protocol that restricted the length of dominance of the ovulatory follicle (Bridges et al., 2008) and in dairy cows that had a spontaneously shorter interval from recruitment to ovulation (Townson et al., 2002; Bleach et al., 2004).

It was clear from experiment 1 that a single injection of $\mathrm{PGF}_{2 \alpha} 5 \mathrm{~d}$ after $\mathrm{GnRH}$ was not effective at regressing the CL, particularly when a new CL was formed in response to the first GnRH of the Cosynch. It is well known that a single treatment with $\mathrm{PGF}_{2 \alpha}$ in the first $5 \mathrm{~d}$ of the estrous cycle is not very effective at regressing the CL (Tsai and Wiltbank, 1998; Miyamoto et al., 2005), although $\mathrm{PGF}_{2 \alpha}$ seems to have clear actions on the developing CL as early as $4 \mathrm{~d}$ after induced ovulation with GnRH (Tsai and Wiltbank, 1998). Nevertheless, in heifers in which an accessory CL was induced by human chorionic gonadotropin on d 10 of the estrous cycle, administration of $\mathrm{PGF}_{2 \alpha}$ on d 2, 4, or 6 after ovulation regressed both the original and the newly formed CL (Howard and Britt, 1990). The authors suggested that an accessory CL induced during mid diestrus was able to respond to an injection of $\mathrm{PGF}_{2 \alpha}$ at earlier stages of luteal development than the typical CL that develops during metestrus. Interestingly, $5 \mathrm{dCoS} 1$ cows that ovulated to the first $\mathrm{GnRH}$ had better CL regression 5 d later when the newly formed CL developed under high $(59.1 \%, 13 / 22)$ rather than low progesterone $(28.6 \%, 2 / 7)$. The same was true for CoS72 [86.4 (19/22) vs. 46.2\% (6/13)]. Therefore, a CL might be responsive to $\mathrm{PGF}_{2 \alpha}$ earlier in development when formed under high systemic concentrations of progesterone. It is also possible that $\mathrm{PGF}_{2 \alpha}$ regression of the pre-existent CL might influence the lifespan of newly formed CL. Finally, another option is that heifers might behave differently from cows. Rabaglino et al. (2010) recently demonstrated that either 1 or 2 injections of $\mathrm{PGF}_{2 \alpha} 12 \mathrm{~h}$ apart in the 5-d Cosynch protocol resulted in similar luteolysis $24 \mathrm{~h}$ after the first injection $\left(1 \mathrm{PGF}_{2 \alpha}=86.9 \%, 2 \mathrm{PGF}_{2 \alpha}=92.8 \%\right)$ and $\mathrm{P} /$ $\mathrm{AI}\left(1 \mathrm{PGF}_{2 \alpha}=48.8,2 \mathrm{PGF}_{2 \alpha}=50.7 \%\right)$.

Because of the shorter duration of the 5-d Cosynch programs, concentrations of progesterone were less and follicle diameters were smaller on the day of the $\mathrm{PGF}_{2 \alpha}$ in $5 \mathrm{dCoS} 1$ and $5 \mathrm{dCoS} 2$ than in CoS72. This effect was observed in both experiments. For cows that ovulated to the first GnRH of the protocols, a new wave of follicles is recruited and the newly selected dominant follicle would have fewer days of development in $5 \mathrm{dCoS} 1$ and $5 \mathrm{dCoS} 2$ than in CoS72. Despite the differences in follicle diameter on the days of injection of $\mathrm{PGF}_{2 \alpha}$ or the final $\mathrm{GnRH}$ of the protocols, treatment did not influence the proportion of cows ovulating before or after the final GnRH. Therefore, the ovulatory capacity of the dominant follicle is similar despite the different stage of development. Although treatment did not influence ovulation within $48 \mathrm{~h}$ of the second $\mathrm{GnRH}$, luteal status at the beginning of the protocols, follicle diameter, and ovulation to the first GnRH of the protocols had effects. The highest probability of ovulation to the second GnRH was observed in cows initiating the protocol in diestrus that ovulated to the first GnRH of the timed AI protocols. On the other hand, the lowest probability of ovulation was observed for cows with low progesterone and no ovulation to the first $\mathrm{GnRH}$ of the protocols. Ovulation to the first $\mathrm{GnRH}$ of the protocol would result in recruitment of new follicles of 4 to $5 \mathrm{~mm}$ $24 \mathrm{~h}$ later, and these follicles would have 6 and $9 \mathrm{~d}$ of development on the day of $\mathrm{AI}$ in $5 \mathrm{dCoS} 2$ and CoS72, respectively. Such follicles with 6 to $9 \mathrm{~d}$ of development are expected to be highly responsive to induction of ovulation with GnRH (Bello et al., 2006; Cerri et al., 2009). Others have demonstrated that cows that ovulated to the first $\mathrm{GnRH}$ of the timed AI protocol also had increased ovulation to the final GnRH (Vasconcelos et al., 1999; Rutigliano et al., 2008). Similarly, cows without a $\mathrm{CL}$ on the day of the first $\mathrm{GnRH}$ of the Ovsynch protocol had reduced ovulation to the final GnRH compared with cows that were cyclic (Galvão and Santos, 2010).

Because of the greater CL regression in cows receiving 2 doses of $\mathrm{PGF}_{2 \alpha}$ on $\mathrm{d} 5$ and 6 after $\mathrm{GnRH}$ versus 1 dose on $\mathrm{d} 7$, protocol synchronization tended to be better for $5 \mathrm{dCoS} 2$ than for CoS72. Estrous response (Archbald et al., 1993, 1994) and luteal regression (Brusveen et al., 2009) in dairy cows improved with an additional treatment with $\mathrm{PGF}_{2 \alpha}$ administered 8 to $24 \mathrm{~h}$ apart. Brusveen et al. (2009) observed that 2 injections of $\mathrm{PGF}_{2 \alpha} 24 \mathrm{~h}$ apart in the Ovsynch protocol increased luteal regression from 84.6 to $95.6 \%$ compared with a 
single injection, although P/AI was not improved. Even though their results showed a greater improvement in CL regression than in the current study (11 vs. 4.8 percentage units), CL regression with a second dose of $\mathrm{PGF}_{2 \alpha} 24 \mathrm{~h}$ after the first was almost the same for cows in the current experiment and those of Brusveen et al. (2009).

A greater proportion of cows receiving CoS72 were observed in estrus on the day of timed AI compared with $5 \mathrm{dCoS} 2$, although both treatments resulted in somewhat low estrous response. Previously, approximately $50 \%$ of the cows receiving the CoS72 were in estrus on the day of timed AI (Hillegass et al., 2008). Because cows in CoS72 had 2 extra days to develop the pre-ovulatory follicle, the follicle was larger on the day of the final GnRH and timed AI, which also resulted in increased concentration of estradiol. Estradiol concentrations are partly related to follicle diameter in lactating dairy cows (Rutigliano et al., 2008), and cows with larger follicles are expected to have more granulosa cells that can increase the secretion of follicular estradiol. These changes usually result in increased expression of estrus in dairy cows.

\section{CONCLUSIONS}

Reduction in the period of follicle dominance by altering the interval from the first $\mathrm{GnRH}$ to $\mathrm{PGF}_{2 \alpha}$ improved fertility of dairy cows. Cows in which the interval from $\mathrm{GnRH}$ to $\mathrm{PGF}_{2 \alpha}$ was reduced from 7 to 5 $\mathrm{d}$ required 2 injections of $\mathrm{PGF}_{2 \alpha}$ within $24 \mathrm{~h}$ to achieve a high proportion of CL that underwent luteolysis. In experiment 1, synchronization in response to the timed AI protocols was similar between CoS72 and 5dCoS2, whereas when a larger number of cows was evaluated in experiment 2, 5dCoS2 tended to improve synchronization to the timed AI protocol because of increased CL regression. Cows in CoS72 ovulated a larger follicle and had increased concentration of estradiol on the day of $\mathrm{AI}$, and a greater proportion of them displayed estrus at AI. Luteal status, ovulation to the first $\mathrm{GnRH}$, and diameter of the follicle on the day of the second $\mathrm{GnRH}$ influenced ovulatory responses within $48 \mathrm{~h}$ of AI. Nevertheless, treatment did not affect ovulation following GnRH at AI or concentration of progesterone $7 \mathrm{~d}$ after AI. On the day of AI, as progesterone concentrations in plasma declined, the probability of pregnancy increased, and the optimum concentration observed was $\leq 0.24 \mathrm{ng} / \mathrm{mL}$. Despite improvements in CL regression in the $5 \mathrm{dCoS} 2$ compared with CoS72, cows that regressed their CL had greater $\mathrm{P} / \mathrm{AI}$ when inseminated following $5 \mathrm{dCoS} 2$ compared with CoS72. Results from the current experiments confirm our hypothesis that a small decrease in the period of follicle dominance, approximately $2 \mathrm{~d}$, by reducing the interval between GnRH and $\mathrm{PGF}_{2 \alpha}$ in a timed $\mathrm{AI}$ protocol improves fertility of lactating dairy cows.

\section{ACKNOWLEDGMENTS}

The authors thank the owner and staff of collaborating dairies for use of their cows and facilities. Our appreciation is extended to Andrew Skidmore (Intervet Schering Plough Animal Health Corp., Union, NJ) for providing Estrumate for this study. Financial support for this study was provided by a grant from Intervet/ Schering Plough Animal Health to J. E. P. Santos.

\section{REFERENCES}

Archbald, L. F., S. Constant, T. Tran, C. Risco, E. Klapstein, and J. Elliott. 1994. Effect of sequential treatment with prostaglandin F2alpha and/or oxytocin on estrus and pregnancy rate of lactating dairy cows. Theriogenology 42:773-780.

Archbald, L. F., C. Risco, P. Chavatte, S. Constant, T. Tran, E. Klapstein, and J. Elliot. 1993. Estrus and pregnancy rate of dairy cows given one or two doses of prostaglandin F2 alpha 8 or 24 hours apart. Theriogenology 40:873-884.

Bello, N. M., J. P. Steibel, and J. R. Pursley. 2006. Optimizing ovulation to first $\mathrm{GnRH}$ improved outcomes to each hormonal injection of Ovsynch in lactating dairy cows. J. Dairy Sci. 89:3413-3424.

Bleach, E. C. L., R. G. Glencross, and P. G. Knight. 2004. Association between ovarian follicle development and pregnancy rates in dairy cows undergoing spontaneous oestrous cycle. Reproduction 127:621-629.

Bridges, G. A., L. A. Helser, D. E. Grum, M. L. Mussard, C. L. Gasser, and M. L. Day. 2008. Decreasing the interval between GnRH and PGF2alpha from 7 to 5 days and lengthening proestrus increases timed-AI pregnancy rates in beef cows. Theriogenology $15: 843-851$

Brusveen, D. J., A. H. Souza, and M. C. Wiltbank. 2009. Effects of additional prostaglandin $\mathrm{F}_{2 \alpha}$ and estradiol-17 $\beta$ during Ovsynch in lactating dairy cows. J. Dairy Sci. 92:1412-1422.

Cerri, R. L., H. M. Rutigliano, R. C. Chebel, and J. E. Santos. 2009. Period of dominance of the ovulatory follicle influences embryo quality in lactating dairy cows. Reproduction 137:813-823.

Chebel, R. C., J. E. P. Santos, R. L. A. Cerri, H. M. Rutigliano, and R. G. S. Bruno. 2006. Reproduction in dairy cows following progesterone insert presynchronization and resynchronization protocols. J. Dairy Sci. 89:4205-4219.

Ferguson, J. D., D. T. Galligan, and N. Thomsen. 1994. Principal descriptors of body condition score in Holstein cows. J. Dairy Sci. 77:2695-2703.

Galvão, K. N., and J. E. P. Santos. 2010. Factors affecting synchronization and conception rate after the Ovsynch protocol in lactating Holstein cows. Reprod. Domest. Anim. doi:10.1111/ j.1439-0531.2008.01220.x. (Accepted)

Galvão, K. N., M. F. Sá Filho, and J. E. P. Santos. 2007. Reducing the interval from presynchronization to initiation of timed AI improves fertility in dairy cows. J. Dairy Sci. 90:4212-4218.

Hillegass, J., F. S. Lima, M. F. Sá Filho, and J. E. P. Santos. 2008. Effect of time of artificial insemination and supplemental estradiol on reproduction of lactating dairy cows. J. Dairy Sci. 91:42264237.

Howard, H. J., and J. H. Britt. 1990. Prostaglandin F-2 $\alpha$ causes regression of an hCG-induced corpus luteum before day 5 of its lifespan in cattle. J. Reprod. Fertil. 90:245-253.

Kasimanickam, R., M. L. Day, J. S. Rudolph, J. B. Hal, and W. D. Whittier. 2009. Two doses of prostaglandin improve pregnancy rates to timed-AI in a 5-day progesterone-based synchronization protocol in beef cows. Theriogenology 71:762-767. 
Kirby, C. J., M. F. Smith, D. H. Keisler, and M. C. Lucy. 1997. Follicular function in lactating dairy cows treated with sustained release bovine somatotropin. J. Dairy Sci. 80:273-285.

Miyamoto, A., K. Shirsuna, M. P. B. Wijayagunawardane, S. Watanabe, M. Hayashi, D. Yamamoto, M. Matsui, and T. J. Acosta. 2005. Blood flow: A key regulatory component of corpus luteum function. Domest. Anim. Endocrinol. 29:329-339.

NRC. 2001. Nutrient Requirements of Dairy Cattle. 7th rev. ed. Natl Acad. Sci., Washington, DC.

Rabaglino, M. B., C. A. Risco, M.-J. Thatcher, I. H. Kim, J. E. P. Santos, and W. W. Thatcher. 2010. Application of one injection of PGF $2 \alpha$ in the $5 \mathrm{~d}$ Co-Synch + CIDR protocol for estrous synchronization and resynchronization of dairy heifers. J. Dairy Sci. 93:1050-1058.

Rutigliano, H. M., F. S. Lima, R. L. A. Cerri, L. F. Greco, J. M. Villela, V. Magalhães, F. T. Silvestre, W. W. Thatcher, and J.
E. P. Santos. 2008. Effects of method of presynchronization and source of selenium on uterine health and reproduction in dairy cows. J. Dairy Sci. 91:3323-3336.

Townson, D. H., P. C. Tsang, W. R. Butler, M. Frajblat, L. C. Griel Jr., C. J. Johnson, R. A. Milvae, G. M. Niksic, and J. L. Pate. 2002. Relationship of fertility to ovarian follicular waves before breeding in dairy cows. J. Anim. Sci. 80:1053-1058.

Tsai, S. J., and M. C. Wiltbank. 1998. Prostaglandin F2 regulates distinct physiological changes in early and mid-cycle bovine corpora lutea. Biol. Reprod. 58:346-352.

Vasconcelos, J. L. M., R. W. Silcox, G. J. Rosa, J. R. Pursley, and M. C. Wiltbank. 1999. Synchronization rate, size of the ovulatory follicle, and pregnancy rate after synchronization of ovulation beginning on different days of the estrous cycle in lactating dairy cows. Theriogenology 52:1067-1078. 